\title{
INTRODUCTION
}

\section{An Urban Resurgence of Social Unionism}

Lowell Turner

Growing inequality is a defining social crisis of our era. In addition to the great gulf that separates the global North and South, domestic economic polarization increasingly characterizes the more prosperous countries of the North. Most obvious in the United States, economic inequality is now widening even in the social democracies of western Europe. It is no coincidence that this growing divide has been accompanied by the declining membership and influence of labor unions, a long-term phenomenon in the United States and United Kingdom, but one that has gained momentum more recently even in countries with stronger labor movements such as Germany.

A revitalization of the labor movement is arguably a necessary precondition for the reversal of this spreading social cancer at the heart of contemporary industrial societies (Weir 2004). Our purpose in this book is not to argue this point but to examine one increasingly significant locus for efforts aimed at union renewal: the urban labor movement. While studies of unions and labor-management conflict have typically concentrated on national, sectoral, and firm-level analysis, regional and local arenas have increasingly become important battlegrounds in union efforts to rebuild economic and political power.

The essays presented here examine the emergence, successes, and failures of contemporary urban-based labor movements, especially in the United States, where such developments are most significant, but also in the United Kingdom and Germany in comparative perspective. Our central question is why such labor movements have emerged prominently and achieved significant successes in some cities but not in others. A comparative analysis points to the central role of two factors: agency, specifically the choices and strategies pursued by union leaders and their organizations; and opportunity structure, located in the presence or absence of particular barriers in the institutional, political, and social context. Although opportunity is important, we also find contrasting outcomes for local labor movement influence given similar opportunities and similar outcomes given contrasting opportunities. Innovative strategies offer potential for strengthening labor's urban-level influence in any circumstances. 


\section{URBAN BATTLEGROUNDS IN A CONTESTED GLOBAL ECONOMY}

As cities in an increasingly global economy swell with immigrant and ethnic minority workforces, economic and social polarization deepens, laying a new groundwork for social unrest even in the prosperous North (Abu-Lughod 1999, 271-85; Sassen 2001, 251-325). As labor comes under increasing pressure at national, sectoral, and firm levels, local/regional arenas, especially the metropolitan area, provide new possibilities for innovation and resurgence (Gordon 1999; Herod 1998, 1-36). And in some cases urban labor movement revitalization contributes directly to battles at the global level. A dramatic example can be found in the high-profile 1999 demonstrations against the World Trade Organization in Seattle.

The story line and significance of the Seattle events are well known (Hawken 2000; Levi and Olson 2000; Steger 2003, 122-26). The fifty thousand demonstrators from across the United States, Canada, and other countries, brought the global justice movement to the public eye, inspiring a series of subsequent mass demonstrations in Quebec, Washington, D.C., Prague, Genoa, and other places. The Seattle demonstrations are widely seen as a watershed for a variety of overlapping movements aimed at protesting the spread of global liberalization without democratic regulation. What is less widely known is the central role played in this story by the labor movement in Seattle.

In an unprecedented alliance with environmental organizations and other social groups, the AFL-CIO and its member unions brought more than half the demonstrators (about thirty thousand by most estimates) to the streets of Seattle in late November and early December of 1999. They did this because Ron Judd and his colleagues at the King County Labor Council persuaded John Sweeney and other labor leaders to take advantage of this historic opportunity. Judd could speak convincingly as the key leader in a series of successful campaigns and coalitions that brought together an increasingly vibrant and cohesive labor movement in Seattle in the 1990s. ${ }^{1}$ Not only did a renewed local labor movement add credibility to Judd's arguments inside the AFL-CIO, the labor council and its member unions provided the organizational foundation on which the "Battle of Seattle" was waged. In short, a reinvigorated local labor movement persuaded national unions to make the critical organizational contribution to a pathbreaking challenge to a prominent global institution.

Seattle and other urban cases show that the revitalization of union strategy and a renewal of union influence are possible even in a broader context of global liberalization and union decline. Recent successes are typically associated with a

1. See, for example, chapter 6 by Greer, Byrd, and Fleron. 
return of social movement unionism, a shift in orientation and strategy from established insider or business union approaches to the innovations of a mobilization-based social unionism. ${ }^{2}$ In examining such processes, we focus on coalition building, arguably both a litmus test and a necessary feature for contemporary labor movement revitalization, whether at international, national, or local levels. More specifically, our purpose is to examine labor-inclusive urban coalitions, their causes and effects, and to compare such coalitions across a range of cities in the United States and Europe.

Thus our focus is on two interrelated processes: the circumstances under which such coalitions emerge, expand, and are (or are not) sustained; and the relative success and specific accomplishments of such campaigns. Explicitly or implicitly, we examine the extent to which such coalitions contribute to the building of a social justice infrastructure, a concept that includes both movement and institution building. Based on active networks of social actors in ongoing relationships and engaged in multiple campaigns, a social justice infrastructure includes both institutions and a transformed local politics in which labor's influence as a progressive social actor expands. In the best cases, labor-inclusive coalition building may contribute to a revitalization of civil society and democratic participation (Johnston 2001; Osterman 2002, 185-88).

\section{OPPORTUNITY AND CHOICE}

Labor in the United States and elsewhere finds itself at a historical conjuncture in which new union strategies become necessary and are in many places emerging. The conjuncture, which can be understood as a product of sweeping political and economic forces (neoliberalism, global liberalization), is characterized for union strategy by a new focus on social coalition building and grassroots mobilization at the urban level. New strategies are targeted especially at service industries such as health care, education, hospitality and building services, as well as other urban-tied industries such as transportation and construction-workforces that in many cases include large numbers of immigrant, minority, and female workers. Manufacturing is still central to the economy and to the labor movement, but for a number of reasons, including capital mobility and a continuing decline in manufacturing employment, it is no longer at the center of union organizing efforts. Our purpose is to explain the emergence of a new kind of unionism aimed at rebuilding capacity and power in the new context-we call it social unionism-to

2. In contrast to "social partnership," the social union concept includes both coalition-based social movement and economic development unionism. 
explain where and why it does or does not emerge in selected metropolitan areas. Our explanation centers on opportunity located in institutions and society-in particular institutional openings and social context-as well as strategic actor choice. Our perspective builds on but is also critical of the narrow scope or outdated analysis of literatures on institutions, civil society, and industrial relations.

To be more specific about the relevant aspects of opportunity, institutions can be enabling or constraining. In the postwar period in all three of our countries, less so in Germany, more so in the United States, labor institutions have gradually changed in ways that make them less enabling and more constraining. In their efforts to break out of constraints, located largely at national, sectoral, and firm levels, unions have in some places opened up a new battleground - the city-that is in important ways more favorable. Thus the spatial dimension takes on new importance. It is in urban environments where unions are most likely to find new allies to help them build new power. It makes a difference whether institutions at the urban level are more open or more entrenched, but in either case strategic innovation by unions aims to exploit opportunity afforded by institutional openings, fragmentation, rigidity, loss of legitimacy, and conflicts among institutional officeholders and power brokers.

Comparative political economy, sociology's new institutionalism, and conventional industrial relations analysis have viewed institutions as enabling or constraining, or as shaping behavior, or as configurations that change over time (historical institutionalism). In our perspective, institutions are also power structures that can provide elements of an opportunity structure-opportunities that open up when institutions lose cohesiveness or legitimacy-that can be used to challenge institutionally embedded power.

Society is important for the social context in which unions seek new allies in their efforts to build capacity and power. The urban context is especially important because that is where people live and social networks are built. Identity politics come into play as defining characteristics of potential social allies - whether the identities are based on ethnicity, immigrant status, gender, religion, neighborhoods, or other identities. ${ }^{3}$ In mobilizing or participating in social coalitions, unions build on bases in society well beyond the workplace to gain public support and build new political power than can also feed back into workplace power.

Thus institutional openings and social context are key elements of the opportunity structure faced by unions seeking to innovate, to build social and political capacity. Although the more opportunity, the better, unions may or may not act on given opportunities, or they may seek to create opportunity with aggressive coalition-based campaigns. Thus the critical role of agency: unions may or may

3. Dan Cornfield develops the central role of worker identities in his conclusion. 
not pursue new strategies such as organizing and coalition building. Whether they do so may depend on leadership change, "bridge builders" (activists with backgrounds and experiences that span different types of social movements), internal organizational reform, or the demands of members or other social groupings. A full explanation of why unions do or do not innovate is beyond the scope of our analysis, although such questions are addressed in the city cases, adding richness to the book even if we can't generalize an argument in this regard. The essential point is that unions have real choices to make as they face the opportunities provided in urban areas by institutional openings and social context.

\section{CASE STUDIES AND CONTRASTING OUTCOMES}

The book's collection of original essays is based on primary research by a group of labor scholars whose attention has shifted toward the surprising revitalization of unions in some cities accompanied by its absence or blockage in other cities. We believe this edited collection on urban coalition building breaks new ground as a comparative study of innovative local union strategies aimed at labor movement renewal through expanded alliances outside the workplace. ${ }^{4}$ The core chapters present case studies of (1) particular urban issues and institutions around which coalition campaigns are built (living wage, community-based development organizations, local politics, central labor councils); (2) "union towns" (New York, Boston, Buffalo, Seattle); (3) “frontier cities" (Los Angeles, Miami, San Jose, Nashville); and (4) European cities in comparative perspective (London, Frankfurt, Hamburg).

For analytical leverage, cities are divided into established union towns, with entrenched, influential labor movements in the postwar period, and frontier cities, with weak or less established labor movements at least until the 1990s. For both groups, selected cities include those in which labor movements are resurgent and those in which labor has made little progress. While chapter authors take distinctive approaches with particular emphases, the overall analytical task is to explain contrasting outcomes, especially with reference to the extent and relative success of union coalition efforts and their spillover effects in the building of social justice infrastructures and a pro-labor progressive local politics.

City cases are selected for a diversity of outcomes. Thus two of the union towns-Seattle and Buffalo-show innovative coalition building resulting in new areas of union influence, while in two others - New York and Boston-social coalition building has been significantly blocked.

4. For earlier efforts that focus on central labor councils see, for example, Ness and Eimer 2001 and Reynolds 2004. 
In similar fashion, we look at two frontier cities-Los Angeles and San Josewhere coalition building has taken off, with positive effects for union influence, and two-Miami and Nashville-where such efforts are in much earlier stages. For both union and frontier cities, contrasting outcomes allow us to sort out and suggest key causal forces at work.

Finally, our European cases cast additional light on causal processes. Why, for example, do we find significant local coalition building efforts in London and Hamburg but not in Frankfurt? What additional insight can we gain by comparing the blockages to coalition building in a union town such as Frankfurt with similar processes in New York and Boston; and by comparing coalition-building efforts in London and Hamburg with both similar and contrasting outcomes in Seattle and Buffalo?

With contrasting outcomes in similar cities and similar outcomes in contrasting cities, our case studies point toward the limitations of conventional social science explanations, whether institutional, political, economic, or cultural. Actor choice, strategic or otherwise, that is not predetermined by external or internal factors takes a central place in this analysis as a causal force in its own right, which is explored from a variety of perspectives throughout the book. Combined with opportunity structures, an elaborated strategic choice perspective goes a good way toward explaining a significant shift toward social unionism in some cases but not others. Although we cannot develop a fully consistent causal argument based on the diverse research and analysis of twenty scholars, these two variables, choice and opportunity, are prominent across all the cases.

Opportunity structure is a central concept in the social movement literature of the past three decades (Tarrow 1998, 71-90). An opening in the political opportunity structure-based on weaknesses in state authority through loss of legitimacy, policy failure, and/or divisions among the powers that be-is often cited as an explanatory factor in the emergence of a social movement cycle (McAdam, Tarrow, and Tilly 2001, 14-15). Although limited in most formulations by a focus only on the state, the concept as appropriately expanded here is useful for our purposes. Opportunities for urban labor movements are located most significantly in the social context and in the institutional arrangements in which union activity is embedded.

In Los Angeles, for example, the social context includes a growing Latino workforce concentrated in low-end jobs and ripe for mobilization through extensive social networks. ${ }^{5}$ The institutional context confronting labor was in important ways wide open for strategic innovation, given a historically weak labor

5. The following city cases, with the exception of Houston, do not include citations since the summaries presented here are based on subsequent chapters in this book. 
movement unencumbered by institutional embeddedness. When key unions adopted grassroots mobilization and coalition-building strategies in the 1990s, the labor movement in Los Angeles grew rapidly in organizing, bargaining, and political influence.

That opportunity structure is not enough is made clear in a comparison between Los Angeles and Houston, where similar social contexts and weak institutional incorporation for labor prevailed. ${ }^{6}$ While Houston does have the institutional disadvantage of its location in a right-to-work state, it shares both the large Latino population and the rather wide-open institutional context. What stands out are differences in the choices and strategies pursued in each city by local union leaders and central labor councils. The innovative approaches that have led to a mushrooming of coalitions and the growth of a cohesive and politically powerful labor movement in Los Angeles have been present until recently to a lesser extent in Houston - and so has the expansion of labor movement influence and power (Meyerson 2004; Karson 2004). ${ }^{7}$

Other cases present variations on the basic argument. In New York and Boston, the emergence of social coalition building has been stunted by the presence of strong insider union locals cutting their own political deals and bargaining agreements. Here the institutional arrangements in which key local unions are embedded have allowed those unions to choose the status quo over innovation, blocking a broader pattern of mobilization and coalition building. In New York, a small number of powerful locals have often been at odds with one another and have shown only limited interest in central labor council coordination, while in Boston a few strategically placed locals have cut deals with local and state governments that have at times benefited their own unions at the expense of broader labor and social interests.

The Seattle and Buffalo cases demonstrate, however, that entrenched unions incorporated in the local political economy can make different choices. In Seattle, innovative union leadership emerged from the previously conservative building trades to join with other unions in the promotion of an increasingly cohesive social unionism. In Buffalo, traditionally strong manufacturing unions have

6. Although Houston is not presented in our case studies, this city is useful for comparison here. In our research we have looked at more cities than can be presented here as detailed case studies, and the larger number of cases has been helpful in working out the comparative analysis (see chapters 2 and 4 , for example, for additional urban cases including Houston).

7. Significantly, a major breakthrough in Houston came with a Justice for Janitors campaign that organized five thousand new SEIU members in the fall of 2005. A coalition strategy modeled on victories in other cities such as Los Angeles offered possibilities for spillover into other Houston campaigns and city politics. See Steven Greenhouse, "Janitors Drive in Texas Gives Hope to Unions," New York Times, November 28, 2005 (available at http://www.nytimes.com/2005/11/28/national). 
banded together in a broad coalition with employers, government, and social actors to promote innovative economic development. Although the Buffalo case does not fit the social movement approach found in most coalition-building efforts in our other city cases, developments there do reflect substantial innovations in union strategies-and also include environmental and social justice dimensions. ${ }^{8}$

As in Los Angeles but in contrast to Miami and Nashville, labor leaders in San Jose, most importantly at the central labor council, have pulled together a cohesive, innovative labor movement that has gained considerable political power, given the opportunities afforded by a significantly open landscape in which labor incorporation was historically weak. In Miami and Nashville, by contrast, where the landscape is similarly open but where labor continues to play a less influential role, union leaders have been slower to build the coalitions necessary to turn things around. The opportunity structure in both cities lacks a relatively homogeneous immigrant/ethnic community as in Los Angeles and to a lesser extent in San Jose. Opportunity matters, shaping the range of choice available to social actors-but opportunity alone is not enough to explain outcomes. More recently in Miami, but not in Nashville, the central labor council together with well-placed activist local unions have consciously promoted selected coalition campaigns aimed at building labor power and a more extensive social justice infrastructure-with some significant successes that demonstrate the potential for continuing advances.

The institutional context is particularly important where states have right-towork laws. Thus unions in Nashville and Miami have a harder row to hoe, which accounts for some of the difficulties those local movements have had in exploiting their particular opportunities. These cases strengthen the argument for the significance of institutional arrangements and cause us to temper our emphasis on actor choice. But as the case studies make clear, Nashville unions have not done what they.could, for example, in reaching out to immigrant groups, while Miami unions are doing this as a central component of a new strategic orientation, with growing success.

Another factor that tempers our analysis is ethnic diversity. In all of our city cases, growing immigrant and ethnic minority workforces occupy a central position in labor's prospects for successful organizing and political clout (e.g., Milkman 2000). Los Angeles has built a labor movement resurgence in part on the mobilization of a large Latino community and its advocacy organizations.

8. On the economic development variant of social unionism beyond the Buffalo case, see also the chapters by Ron Applegate (community-based development organizations), David Reynolds (regional power building), Ian Greer (Hamburg and Seattle), and Nari Rhee and Julie Sadler (San Jose). 
Greater ethnic and immigrant diversity in Miami and Nashville raises the bar for a coalition-based social unionism, and one could argue that this is a decisive factor that again undermines our emphasis on actor choice. Yet the difference in innovative initiatives remains, with a broad social union fermentation in Miami that is lacking so far in Nashville. And in the San Jose case, a substantial Latino community is balanced by an equally large Asian population (about 25 percent each in the metropolitan area), an ethnic diversity that has not limited the labor council's grassroots efforts, especially in the Latino community.

Given very different institutional contexts, our European city cases are admittedly a bit of a stretch for this comparative analysis. Still we find useful insights and to some extent confirming outcomes as we move across national boundaries. More work needs to be done in this broadened field of comparison, but in the meantime the signposts are promising. Frankfurt, for example, looks very much like New York and Boston in important ways: existing institutional arrangements are not favorable to alternative strategies nor have the dominant unions pursued them. Several unions, including the powerful Metalworkers Union (IG Metall), have their national headquarters in Frankfurt and are focused on sectoral bargaining and nationally coordinated campaigns. There has been little opening for independent local initiatives, especially innovations in strategy such as coalition building to promote a more socially activist urban labor movement. Nor have local unions made much effort in this regard.

In London, unions have also focused on national strategies to the detriment of local initiatives. Yet here firm-level bargaining (as opposed to the sector bargaining that dominates German collective bargaining) has opened the door for local and regional campaigns. Important unions such as the Transport and General Workers Union (TGWU) and UNISON (the dominant public sector union) have in some cases built coalitions with other social actors and community groups in London to campaign for local legislation such as living wages and for targeted multifirm organizing such as sustained campaigns at the Canary Wharf corporate and financial complex in East London. Key local unions, with and without national support, have developed significant place-based strategies. In contrast to Frankfurt, the London case offers more institutional opportunity, although it is limited enough that differences in the strategic choices of local actors appear significant.

Hamburg offers a middle case, in which local innovation is tempered but not overwhelmed as in the F́rankfurt case. Here, Germany's two largest unions, IG Metall and ver.di (Vereinte Dienstleistungsgewerkschaft or United Services Union, a vast service workers union that spans the public and private sectors) have each built winning coalition campaigns around particular local issues, but without much spillover into a more cohesive urban labor movement. That Ger- 
man institutions, in spite of a well-anchored national and sectoral focus, do not present insurmountable barriers to ongoing coalition-based social unionism is demonstrated in the case of Stuttgart. Here determined local actors, especially ver.di, have developed coordinated campaigns that have both brought in other social actors and influenced national mobilizations in defense of the welfare state in 2003 and 2004. As in the Seattle case, the Stuttgart labor movement's activism laid a foundation for events of national import. ${ }^{9}$

To summarize case-study findings, we have identified a significant break with traditional business or insider unionism in many urban contexts. The divergent path is characterized by what we call social unionism, in most cases based on social movement approaches such as grassroots mobilization and coalition building. While in some cities such initiatives are limited or suppressed, in others we find an expansion of innovation that broadly overtakes traditional approaches. Our cases demonstrate the decisive significance of two factors in the emergence of urban social unionism, as indicated by the spread of social coalition building as a prominent feature of local labor movement activity. The first is the range of opportunity faced by unions in a given urban context. The most significant aspects of the opportunity structures appear to be located in existing institutional arrangements and social context. Institutions and patterns of labor incorporation (or exclusion) - the presence or absence of powerful deal-cutting insider unions, the presence or absence of right-to-work laws - can either open the door for innovation and revitalization or block the way. Cross-national institutional differences are also significant in this regard, as Jefferey Sellers shows. The social context can offer more or less in the way of potential coalition partners and social networks through which mobilization efforts can spread. Immigrant groups are particularly important in contemporary organizing efforts, and in this regard relative homogeneity in immigrant/ethic composition is a significant factor in the opportunity structure.

The second and decisive factor in the emergence of socially activist urban labor movements is the strategic choices made by local unions. New or reformed local leaders and bridge-building activists have a range of choices even in the most difficult circumstances. Although institutional and social contexts offer more or less opportunity, local unions have important choices to make. They can take advantage of openings to move toward social mobilization and coalition building, or they can choose to stay with the traditional approaches they know. Strategic innovation is to be sure not an up-or-down choice. Reform-minded leadership is most likely to emerge where real possibilities for reform are apparent. And the

9. Although the Stuttgart case is not a subject of study for this book, related research indicates the significance of developments there for a broader comparative analysis. 
success of such leaders-as shown in the cases presented by David Reynolds in chapter 4-also depends on the development of appropriate leadership skills.

As Dan Cornfield and Bill Canak argue in chapter 9, the strategies that unions and other social actors pursue depend in large part on how they choose to frame the issues and to mobilize resources. Coalition building is based on a reframing that emphasizes common interests with other social actors, and it is also a potentially effective way of expanding available resources. Thus even when barriers are great it is possible for innovative, aggressive unions to develop strategies aimed at breaking through the constraints, and in such situations-Miami, Boston, Stuttgart, London-significant advances for social unionism cannot be ruled out.

If the range of outcomes runs along a continuum, at one end are cases of considerable opportunity and strategic innovation, such as Los Angeles and Seattle, while the other end is occupied by cases of limited opportunity and strategic traditionalism, such as Nashville and Frankfurt. We are impressed, however, and our analysis is colored, by the fact that in any case unions can use social movement or economic development strategies to push the envelope. It is important for analysts as well as trade unionists to know the constraints, but our findings persuade us that innovative union strategies can make gains in any context.

\section{COUNTERARGUMENTS}

We have combed through our case studies to see if alternative arguments make sense. Economic structure or restructuring is obviously important for the circumstances labor and other social actors face at any level of engagement. As manufacturing disappears from many urban areas, or shifts from large-scale operations to light manufacturing, or disperses into suburbs and exurbs, union membership takes a beating while opportunities for new organizing are less favorable. A corresponding expansion of service sector employment-in health care, education, building services, domestic services, transportation - requires innovative organizing strategies and confronts unions with new challenges. Changes in economic structure clearly affect the constraints and opportunities faced by labor and its potential allies. Such processes characterize all advanced industrial societies at national, regional, and local levels. Although the pace, extent, and substance of change vary, all of our city cases show broadly similar processes of economic restructuring, with impacts powerful enough to overwhelm the differences for union innovation. We find no explanatory help in the variations that exist from city to city in the specific content of contemporary economic change.

Nor do existing local political structures or processes appear decisive. Stephanie 
Luce does find that urban governance structure matters in that local governments with city administrators are likely to be resistant to living wage legislation and implementation. Sustained pressure from labor and its social alliances is especially necessary to counter such resistance. But neither this nor other structural differences in local political frameworks appear linked to the rise or relative success of social coalition building. Contrasting national political and economic institutions do matter for the range of choice in each country, as Jefferey Sellers shows in chapter 2. But that range is wide enough that locally specific opportunities and choices can be decisive, and we do find similar as well as contrasting outcomes in countries with very different institutional frameworks.

Closely related to political structure and process is government policy toward unions. Friendly governments such as those led by mayors Ken Livingstone in London and Antonio Villaraigosa in Los Angeles can offer significant support to union organizing and coalition campaign efforts. Yet historically labor-friendly governments in cities such as New York and Frankfurt have done little to open the door for innovative coalition-based labor strategies. And in Los Angeles, San Jose, and Seattle, resurgent labor movements have transformed local politics in ways that have weakened opposition and strengthened support for union-backed public policy.

The relative effects of globalization, whether the emphasis is on economic integration, intensified competition, or neoliberal governance, also do not help very much in explaining the variations we have found. An expanding immigrant workforce, for example, is important in all our urban cases, including the more recent "interior globalization" represented in this book by the Nashville case. We began this project with the assumption that global cities such as New York, Los Angeles, London, and Frankfurt would display converging workforce characteristics, including a vast influx of low-end immigrant labor and a growing economic and occupational polarization, which might lead to converging strategic innovations by labor and its social allies. What we found, instead, was that all of our cities are characterized by increasing global penetration and expanding immigrant workforces, and that union strategies vary as much across the classic global city cases as between more and less globally integrated urban areas.

Finally-although we cannot claim to have exhausted the list of potential counterarguments-employer opposition is widely cited as a powerful explanatory force driving union decline. Across our U.S. cases, however, aggressive employer opposition is almost a given in the present era. Although especially intense and effective in Nashville and Miami, where right-to-work laws prevail, antiunion employer strategies are nonetheless standard practice throughout the U.S. political economy. Battles to organize and negotiate at major hotel chains, for example, require intensive comprehensive campaigns in Los Angeles just as they do in 
Boston and Miami-and the same is true for London. Even where institutions of social partnership mute the opposition in countries such as Germany, we nonetheless find quite different union strategies and social coalitions in cities such as Frankfurt, Hamburg, and Stuttgart.

In contrast to the conventional arguments outlined above, our analysis points to the influence of social and institutional contexts in shaping opportunities for innovation, while privileging the independent decision-making capacities of social actors such as labor unions, central labor councils, and the social coalitions in which they participate.

\section{REVITALIZING THE LITERATURE}

Because we believe that national and global politics build to a large extent on the local, the growth of social coalitions and networks at the urban level affords an important window into the prospects for progressive reform in an era dominated by neoliberal globalization. This perspective also contributes to a refocusing of labor scholarship somewhere between the traditional and often narrow framework of industrial relations and the broad political and institutional approaches of comparative political economy. What is missing from much previous work in these fields is civil society. Yet labor today operates not just at the workplace, firm, sector, and in the grand arenas of national politics but also as a social actor, one among many, drawing on logics of social movements, urban conflict, and a politics of place.

The diminishing substance of contemporary civil society, like the decline of the labor movement, has been a subject of much analysis and a source of widespread concern (Putnam 2000; Skocpol 2003). In this regard, efforts to revitalize the labor movement can be viewed as an important element in efforts to revitalize civil society. Urban-based coalition building can expand union influence, and vice versa, in the reconstruction of modern social justice infrastructures. Labor movement revitalization, where it does occur, offers a potentially significant contribution to struggles for broader social transformation..$^{10}$

In this context, the studies presented here aim to deepen our understanding of the possibilities for labor's contribution to a broader renewal of progressive politics and institutional reform. The analysis confronts existing theoretical perspectives: the transformation of industrial relations (Kochan, Katz, and McKer-

10. The recent and growing literature on labor movement revitalization includes, among other work, Bronfenbrenner et al. 1998; Turner, Katz, and Hurd 2001; Nissen 2002; Cornfield and McCammon 2003; Frege and Kelly 2004; Fantasia and Voss 2004; and Milkman 2006. 
sie 1986), a prominent school of thought from which we take our grounding in strategic choice but one that is limited by an overemphasis on the firm and workplace, missing the broader social context; varieties of capitalism (Hall and Soskice 2001), now prominent in comparative political economy, a perspective limited by an assumption of institutional stability that allows little room either for labor movement revitalization or for a renewal of progressive political and economic participation and policy; a promising recent literature on actor-driven institutional change (Streeck and Thelen 2005) that nonetheless focuses mainly on incremental neoliberal advances in a context of global liberalization; and a social movements literature now broadened into a framework of contentious politics (McAdam, Tarrow, and Tilly 2001), yet still limited by a focus on protest aimed at the state, with a relative neglect of the contemporary potential of labor as a social movement actor targeting the multinational corporations that dominate the global economy. Emphasizing actor choice, strategic innovation, and coalition building, our book contributes to an expanded theoretical perspective that brings back labor and civil society with insights from studies of labor revitalization, social movements, democratic renewal, and institutional reform.

\section{CONCEPTS AND DEFINITIONS}

The following concepts should be seen only as clarifications rather than as attempts at precise definition. In any case, our creative group of chapter authors could never be pinned down to strictly harmonized usages. These loose definitions express an attempt by the editors to generalize our meanings as best we can, without any attempt to jam current or future work into straitjackets of restrictive analysis. Flexibility is after all a watchword of the day.

We use the terms city, local level, local arena, region, and metropolitan area more or less interchangeably. Our intent is not to provoke our colleagues in the field of urban studies (who we very much hope will read this book and join us in a dialogue about the place of labor in urban discussions), but for our purposes here urban area refers to the entire metropolitan region. While much of our research centers on the core city, since that is where much current labor movement action occurs, organizing efforts in the suburbs and surrounding areas, often as an extension of city campaigns, are significant for the prospects for successful union innovation.

Labor movement revitalization is also a term that gets used in various ways not only in this book but throughout the literature. In some usages, revitalization refers to new vitality and strategic innovation, including coalition building and grassroots mobilization. In other cases, the term refers to the accomplishments 
and breakthroughs - in organizing, collective bargaining, and local politics-to which innovative unions contribute. My own view is that labor movement revitalization should appear on the former side of the equation, referring to new vitality: innovation, internal organizational reform, newly awakened unions pursuing activist strategies aimed at concrete successes. Revitalized unions may or may not achieve their goals, just as a revitalized army or political party may or may not win the battle. ${ }^{11}$

Social movement unionism is used here to indicate an activist mobilizationbased unionism that, in contrast to established insider unionism, pushes for substantial social change (Waterman 1993; Turner and Hurd 2001). The concept is at once condensed and broadened in the term social unionism to encompass both social movement approaches and other coalition-based innovations in areas such as economic development. Social unionism should not be confused with social partnership, which is typically an insider form of unionism. Where social partnership is strong and stable-Norway, Sweden, and Finland, for example-a more activist social unionism may not appear on the radar screen. Where social partnership relationships have weakened, as in Germany, there are new stirrings of social unionism. And in nations such as the United Kingdom efforts to build insider social partnership at the firm level are counterposed to alternative grassroots mobilization efforts.

There is a difference between social movement unionism and social movements (Turner and Hurd 2001, 11-12). The latter are much broader and happen in the fullest form at particular historical moments, such as the 1930s and $1960 \mathrm{~s}^{12}$ Social movement unionism, by contrast, refers to union strategies that use social movement-type approaches, such as coalition building, grassroots mobilization, aggressive organizing, demonstrations, and civil disobedience, and which typically operate outside established channels. Such approaches are more difficult when social movements are not widespread, and thus the contemporary situation presents major challenges for innovative unions, which must push upstream. There are no broad social movements to sweep unions along in their efforts at power building - which is one reason why so many unions have resisted innovation. Coalition campaigns that spill over into other campaigns and influence local politics, in cities such as Los Angeles, San Jose, and Seattle, may take on the

11. This formulation is not common usage in some of the chapters that follow, as well as in this author's previous work. In this new area of inquiry, based on contemporary developments, research and analysis are still in the early stages. Contradictions in usage of the term "labor movement revitalization" in my own case reflect (at best) a trial-and-error process of concept development.

12. The social movement concept used here is contrasted to the narrower "new social movement" characterization that, like the term "labor movement," applies to particular interest advocacy (such as environmental or women's rights) that may or may not function as an active "movement." 
characteristics of social movements and are based on social movement-type strategies. But they are not social movements in the full meaning of the term.

Social coalition building refers to alliances of social actors, sometimes with the leadership of or at least participation by labor unions, whose campaigns are typically aimed at firms and governments. ${ }^{13}$ As campaigns gain steam, or sometimes at the outset, local officials and candidates sign on to press demands on their own governments or firms doing business in the city, not incidentally to win popular support. And when campaigns focus on economic development, the participation of key employers and local governments is essential for success. Social coalitions seek among other things to contribute to an expanded social justice infrastructure that includes both movement and institution building. Based on active networks of social actors in regular relationships, a social justice infrastructure includes both institutions-such as the living wage boards, community-based development organizations, and central labor councils considered in this book—and a transformed local politics.

The social union concept includes, therefore, both social coalition building and the drive to expand a social justice infrastructure. Coalition-based campaigns are typically framed as battles for social justice. Expanded union participation in alliances with social groups acknowledges the multiple identities so important to the politics of contemporary campaigns. Urban labor movements find essential allies in social groups organized around the interests of immigrants, women, minorities, consumers, and communities. In many cases, such alliances become possible only in conjunction with internal union reform efforts, including organizational restructuring and leadership change, that expand internal inclusiveness and in so doing lay the groundwork for externally inclusive coalition campaigns. Identity-based social coalition building is a defining characteristic of the current transformation, elaborated in Dan Cornfield's concluding chapter, from manufacturing-based industrial unionism to the multijurisdictional unionism of an increasingly service-based economy.

In referring to institutions, we build on the standard contemporary definition found in Hall and Soskice $(2001,9)$ : "a set of rules, formal or informal, that actors generally follow, whether for normative, cognitive or material reasons, and organizations as durable entities with formally recognized members, whose rules also contribute to the institutions of the political economy." This broad definition reflects common usage, and for our purposes it includes the structures and regularized processes through which labor, business, government, and other social actors pursue their interests and interactions. Unlike much contemporary insti-

13. For a sample typology of union coalition building, see, for example, Frege; Heery, and Turner 2004. 
tutional literature, we do not take institutions as given but rather as the product of past, present, and future battles in which, for example, social movements can and do reform or transform institutions (Turner 2003).

\section{ISSUES AND CASE STUDIES}

To lay the groundwork for the urban case studies, the essays in part 1 present several issues central to the efforts of social coalition building at the local level. Stephanie Luce opens with an analysis of the living wage campaigns that have resulted in new legislation in more than seventy U.S. cities since 1994. Almost always including the participation if not the leadership of unions, living wage campaigns have brought together community, religious, ethnic, and immigrant organizations in coalitions that have won public support and often spilled over into further collaboration. Ron Applegate highlights the institution-building capacity of community coalitions. In the community-based development organizations (CBDOs) he examines, unions, long at odds with such efforts, have begun to enter the local economic development arena in alliances that build community power and at the same time provide bases for further collaboration. As cuttingedge cases demonstrate, a comprehensive approach enables both unions and CBDOs to challenge the political and economic constraints that have blocked their respective efforts to advance agendas of social justice.

In the broad cross-national comparative analysis offered by Jefferey Sellers, national infrastructures matter yet still leave a range of choice for local actors based on urban context, including the strength of community organizations and the nature of the policy-making process. Sellers emphasizes that local alliance building allows unions to expand opportunities present in the social and political context. And in another multicity case study, David Reynolds demonstrates the capacity of local unions to build regional power in the United States. Transformed by a new generation of activist leaders, previously dormant central labor councils have emerged as focal points in coalition campaigns that bring social actors together to expand progressive political influence across a range of urban areas. Such initiatives move beyond traditional efforts to elect pro-labor candidates toward more comprehensive strategies for engagement in regional governance.

The chapters in part 2 present case studies of "union towns" in the United States, where insider unions have long occupied positions of well-established political and economic influence. Heiwon Kwon and Benjamin Day examine the Boston case, where a few political deal-making unions have made gains for their own members at the expense of a broader mobilization to expand organizing efforts and a more cohesive social unionism. Ian Greer, Barbara Byrd, and Lou Jean 
Fleron show the critical role of political entrepreneurship in innovative union efforts to build coalitions that have moved traditional unions in Seattle and Buffalo into central positions of influence in the economic development arena. Finally, Marco Hauptmeier and Lowell Turner provide a bridge to the next section in a comparison between the limitations of social unionism in New York and the transformation in Los Angeles of traditionally weak unions into a politically powerful labor movement, building in part on coalitions rooted in a growing Latino community.

Part 3 builds on the Los Angeles case to consider urban areas in which unions did not exert significant political and economic influence prior to the 1990s. For Miami, Bruce Nissen and Monica Russo explain both the blockage of union influence in an area characterized by diverse immigrant groups in a right-to-work state as well as the more recent transformation of the central labor council and the potential for an expansion of strategic social unionism. Daniel Cornfield and William Canak identify a similar blockage in Nashville, illustrating the lack of labor mobilization with an in-depth study of recent immigration patterns and the continuing distance between labor and immigrant support groups. Coming full circle back to a successful case similar in some ways to Los Angeles, Nari Rhee and Julie Sadler show the pathbreaking role played in San Jose by innovative leadership at the central labor council, in building the coalitions and political power necessary to redefine the labor movement as an influential actor in public policymaking processes.

Going solo this time, Ian Greer provides a bridge between U.S. and European cases by opening part 4 with a comparative study of Hamburg and Seattle. Although labor in Seattle coalesced earlier than Hamburg as a cohesive labor movement, unions in both cities have in recent years pulled together impressive coalition campaigns around particular issues. Jane Holgate and Jane Wills present a mixed picture for labor in London, where coalition-based living wage and union organizing campaigns have broken new ground in a labor movement still largely characterized by national, firm-specific, single-union campaigni. Otto Jacobi's Frankfurt story concludes the case studies with a graphic demonstration of the barriers to local labor campaigns in a context marked by strong labor institutions focused at the national, sector, and firm levels.

Finally, Dan Cornfield adds a systematic analysis of patterns of immigration and identity for processes of labor movement revitalization, while at the same time making a heroic effort to summarize our collective insights into the meaning and significance of contemporary union coalition-building efforts.

And now, please join us where the rubber meets the urban road. ... 